\title{
Calcium and Magnesium Dynamics in Litter in a Successional Forest Ecosystem, Under Hydroperiod
}

\author{
Amanda Maria de Sousa Diogenes Ferreira ${ }^{1}$, Francisco de Assis Oliveira ${ }^{2}$, Steel Silva Vasconcelos ${ }^{3}$, \\ José Renan da Silva Guimarães ${ }^{4}$, Luciedi de Cassia Leôncio Tostes ${ }^{1}$, Francisco Oliveira Cruz Junior ${ }^{1}$, \\ João da Luz Freitas ${ }^{1}$, José Victor Torres Alves Costa ${ }^{5}$, Angela Maria Braga Lobato ${ }^{6}$ \\ $\&$ Adriano Castelo dos Santos ${ }^{1}$ \\ ${ }^{1}$ Instituto de Pesquisas Cientificas e Tecnológicas do Estado do Amapá, Núcleo de Biodiversidade, Macapá, \\ Amapá, Brazil \\ ${ }^{2}$ Instituto de Ciências Agrícolas, Universidade Federal Rural da Amazônia, Belém, PA, Brazil \\ ${ }^{3}$ Embrapa Amazônia Oriental, Belém/PA, Brazil \\ ${ }^{4}$ Amcel Amapá florestal e Celulose, R. Cláudio Lúcio Monteiro, Santana, AP, Brazil \\ ${ }^{5}$ Superintendência Federal de Agricultura do Amapá, Macapá, AP, Brazil \\ ${ }^{6}$ Agência de Defesa e Inspeção Agropecuária do Estado do Amapá, Macapá, AP, Brazil \\ Correspondence: Amanda Maria de Sousa Diogenes Ferreira, Instituto de Pesquisas Cientificas e Tecnológicas \\ do Estado do Amapá, Núcleo de Biodiversidade, Rod. JK, km 10-Fazendinha, CEP 68.903-419, Macapá, Amapá, \\ Brazil. Tel: 55-96-99132-9437. E-mail: amandadiogenes1@hotmail.com
}

Received: August 12, 2021

doi:10.5539/jas.v13n11p105
Accepted: September 19, $2021 \quad$ Online Published: October 15, 2021

URL: https://doi.org/10.5539/jas.v13n11p105

\begin{abstract}
This study was part of the Manipulation of Moisture and Nutrient Availability in Young Regrowth Forests in Eastern Amazonia Project (MANFLORA). The experiment was designed in completely randomized blocks containing control and irrigated treatments during the dry period ( $5 \mathrm{~mm}$ of water/day), with four repetitions each. The monthly mean litter values ranged from 316.10 to $997.90 \mathrm{~kg} \mathrm{ha}^{-1}$ month $^{-1}$. The magnitude of this phenomenon can be explained by the functional role of the floristic structure, represented by the species Myrcia sylvatica (G. mey) DC., Myrcia bracteata (Rich) DC., Miconia ciliata (Rich) DC., Lacistema pubescens Mart., Lacistema aggregatum (Berg.) Rusby, Vismia guianensis (Aubl.) Choisy, Cupania scrobiculata Rich. and Ocotea guianensis Aubl., which constituted the determinant factors, associated with the hydroperiodic effect and ecosystem manipulation. The monthly mean of the analytical results of mass treatments were significant $(\mathrm{P}<$ 0.05), however, when compared annually there was no significance, which indicates seasonal influence, since the period of greatest deposition is the dry one, regardless of the water manipulation along the period studied. Only in time the mass values of $\mathrm{Ca}$ and $\mathrm{Mg}$ were not significant for treatment $(\mathrm{P}<0.05)$. The amount of $\mathrm{Ca}$ was significantly $(\mathrm{P}<0.05)$ higher than that of $\mathrm{Mg}$.
\end{abstract}

Keywords: biogeochemistry, eastern Amazon, irrigation, litter, secondary forest

\section{Introduction}

Tropical regions are characterized as locals of intense luminosity, abundant rainfall, and predominance of soils with clay minerals of low activity. However, it is precisely in these regions that it is observed a high level of plant biodiversity. Among these characteristics, the nutrient poverty of the soil caused most studies on nutrient cycling to focus on biotic compartments, mainly litter, of easier measurement (Klinge \& Rodrigues, 1968; Clevelário Júnior, 1988; Summers, 1998). Therefore, litter production is considered the most important mean of transferring essential elements from vegetation to soil (Nascimento et al., 2018). Besides, it is fundamental for the knowledge of the structure and functioning of forest ecosystems.

Litter can be defined as all types of biogenic material in different stages of decomposition, which represents a potential source of energy for consumer species. Nonetheless, many biotic and abiotic factors influence in litter deposition, such as: vegetation type, latitude, altitude, relief, temperature, rainfall, light availability during growing season, photoperiod, evapotranspiration, deciduousness, successional stage, water availability and 
amount of nutrients in the soil. Litter deposition results from the interaction of these factors and, according to the peculiarities of each system, one factor may prevail over the others (Vitousek \& Sanford, 1986; Odum, 1988; Golley et al., 1978; Mateus et al., 2013; Zhang et al., 2014; Silva et al., 2015).

Low water availability is considered one of the main conditions of environmental stress (Santos, 1996) and it is of extreme importance for metabolical activity and leaf survival, being the survival ability during hydric stress determinant for the distribution and productivity of plants (Pimentel et al., 1990). In regions prone to water deficit, due to low rainfall or irregular rainfall distribution, the growth of planted forests in height and diameter is limited (Santos et al., 2020). For this reason, water scarcity is a concern in tropical forests and may lead to an environmental collapse, in which several species may disappear if these ecosystems undergo consecutive droughts (Santos, 1996; Nepstad et al., 1998). Therefore, the necessary amount of water and nutrients are major factors, as their lack and/or excess may compromise the production and/or productivity of forest species (Sobrinho et al., 2020).

Studies on nutrient cycling are of fundamental importance for the knowledge of the structure and functioning of any ecosystem. Phosphorus $(\mathrm{P})$, calcium $(\mathrm{Ca})$, magnesium $(\mathrm{Mg})$, potassium $(\mathrm{K})$ and nitrogen $(\mathrm{N})$ are essential elements which are determinants in plant growth, because they have considerable importance in plant metabolism and function (Barroco Neta \& Nishiwaki, 2018). Considering the importance of nutrient cycling for the soil, this is directly related to seasonality, as the amount and decomposition of litter varies according to rainfall.

The aim of this study was to quantify the monthly accumulated litter production and the concentration of $\mathrm{Ca}$ and $\mathrm{Mg}$ in successional forest, under water manipulation, with the following question: can water availability during the dry period alter the biogeochemical cycles of $\mathrm{Ca}$ and $\mathrm{Mg}$ in a successional ecosystem? If biogeochemical cycles vary according to the hydroperiodic phenomenon, then they have seasonal dynamics.

\section{Material and Methods}

\subsection{Study Area}

The study was developed in the Manipulation of Moisture and Nutrient Availability in Young Regrowth Forests in Eastern Amazonia Project (MANFLORA), which began in 1999, when forest regeneration was 12 years old. The experiment was carried out at the Fresh Water Fish Farming Station (EPAD), which belongs to the Federal Rural University of the Amazon (UFRA), in the region of the middle Apeú River, Castanhal, in the Praquiquara River basin $\left(1^{\circ} 19^{\prime} \mathrm{S}, 47^{\circ} 57^{\prime} \mathrm{W}\right), 80 \mathrm{~km}$ away from Belém.

The surrounding landscape is marked by secondary forests, agroecosystems and pastures. According to Falesi et al. (1980), in the Bragantina Zone there existed the humid tropical forest that, with colonization and agriculture practice, through successive cuts and burnings, was modified, which caused the formation of a mosaic of different successional stages, with predominance of several agroecosystems, mainly pasture. The settlement under study was modified due to shifting agriculture, which includes the cultivation cycle of corn, cassava and bean, for 1 to 2 years, followed by fallow, which was abandoned in 1987. The region's relief is slightly wavy to wavy, under forest vegetation, mostly constituted by a flattened surface, dissected in flat top hills, with small altimetric variation. It presents a dystrophic yellow latosol of clayey texture and concretionary laterites (Tenório et al., 1999).

The granulometric composition in the first $20 \mathrm{~cm}$ is $40 \%$ clay, $30 \%$ sand and $30 \%$ silt. Concretions represent $16 \%$ of the volume of superficial soil $(0-10 \mathrm{~cm})$, with organic $\mathrm{pH}$ of 5.0 , organic $\mathrm{C}$ of $2.2 \mathrm{~kg}$, organic C stock of $2.9 \mathrm{~kg}$ $\mathrm{m}^{-2}$, total $\mathrm{N}$ of $0.15 \%$, C:N 14.4, and Mehlich-1 extractable phosphorus $1.58 \mathrm{~kg} \mathrm{mg}^{-1}$ (Rangel-Vasconcelos, 2002).

The climate, according to the Köppen classification, is type Am3, with annual mean rainfall of 2000-2500 mm; $70-90 \%$ of the annual rainfall occurs between January and July, while the dry period occurs from August to December, with dry months being considered when rainfall was lower than $100 \mathrm{~mm}$ (Table 1). 
Table 1. Rainfall distribution and intensity during experimental period at the site. The dry months were considered when rainfall was lower than $100 \mathrm{~mm}$. The dry period included rainfall from August to December

\begin{tabular}{lll}
\hline & \multicolumn{2}{c}{ Year } \\
\cline { 2 - 3 } & 2000 & 2006 \\
\hline Annual rainfall (mm) & 2399 & 2756 \\
Minimum monthly rainfall $(\mathrm{mm})$ & 66 & 63 \\
Maximum monthly rainfall $(\mathrm{mm})$ & 291 & 434 \\
Total rainfall in dry period $(\mathrm{mm})$ & 694 & 630 \\
\hline
\end{tabular}

The analysis of the seasonal rainfall climatology confirmed previous results (Figuera \& Nobre, 1990; Rocha, 2001; Vieira et al., 2004), which demonstrated that most part of the Amazon shows two distinct periods: dry, with monthly mean rainfall below $100 \mathrm{~mm}$, and rainy, with mean rainfall above $200 \mathrm{~mm} /$ month. The daily mean air temperature ranges from 24.7 to $27.3{ }^{\circ} \mathrm{C}$, with a maximum of 30.1 to $32.7{ }^{\circ} \mathrm{C}$ and a minimum of 19.2 to $24.2^{\circ} \mathrm{C}$. Relative air humidity has annual mean values ranging from 78 to $90 \%$ (Martorano \& Pereira, 1993).

\subsection{Sampling Procedures}

For this, a floristic survey was performed in the experimental plots, at the beginning of the project, in 1999, that is, when the forest was 12 years old, and later another, in 2006. The tree vegetation was inventoried in four $10 \times$ $10 \mathrm{~m}$ plots, where individuals of tree species with a diameter of $1.3 \mathrm{~m}$ in height (DBH) $\geq 1 \mathrm{~cm}$ were measured. Each measured tree was identified with a numbered metal plate and identified up to the species level. The botanical material was collected and herborized in the Herbarium of Embrapa Eastern Amazon.

The procedure of area selection for the collection of depositional flow samples from the biogeochemical matrix was performed at sites with full canopy cover and homogeneity of ecosystem characteristics to obtain a flow sample with greater accuracy. Sample collection was carried out following collectors' location, according to the experimental design of randomized blocks, with repeated measures through time.

The ecosystem was divided into four randomized blocks, with two treatments: control and irrigation (irrigation during the dry season). Each treatment plot measured $20 \mathrm{~m} \times 20 \mathrm{~m}$, with central plots of $10 \mathrm{~m} \times 10 \mathrm{~m}$, that contained three collectors of biogeochemical matrix (depositional litter). The experiment was evaluated during 2000 and 2006, while treatments remained during the interval of the evaluated years.

In the irrigated treatment, $5 \mathrm{~mm}$ of water/day were added for about 30 minutes during the dry season in the late afternoon with irrigation hoses (Santeno), systematically allocated in the central plots (Figure 1). The amount of daily irrigation applied corresponded to the estimation of regional evapotranspiration per day, in secondary forest in the Amazon (Lean et al., 1996; Jipp et al., 1998; Sommer et al., 2002).

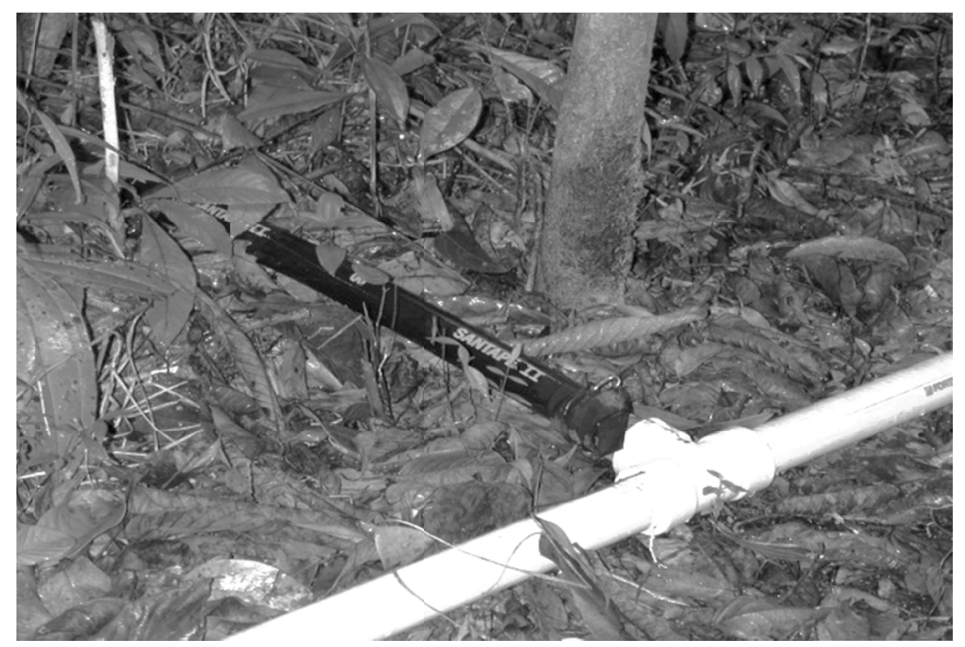

Figure 1. Irrigation system implanted in irrigated treatment in the successional forest at the UFRA Station, Castanhal/PA 
In 2001, irrigation tapes were spaced $4 \mathrm{~m}$ apart. In subsequent irrigations, the distance between the tapes was reduced to $2 \mathrm{~m}$ in order to obtain a more uniform water distribution. The total applied irrigation varied from 630 to $790 \mathrm{~mm}$ per dry season, which represented a 100-200\% increase in water intake in the dry season, and an increase in annual rainfall of $21-34 \%$.

The collectors measured $1 \mathrm{~m}^{2}(1 \mathrm{~m} \times 1 \mathrm{~m})$ and $0.10 \mathrm{~m}$ in depth, suspended from the ground at $0.3 \mathrm{~m}$. The sampling frequency was weekly in order to reduce the nutrient leaching process in samples which were still in the collector (Proctor, 1983) (Figure 2).

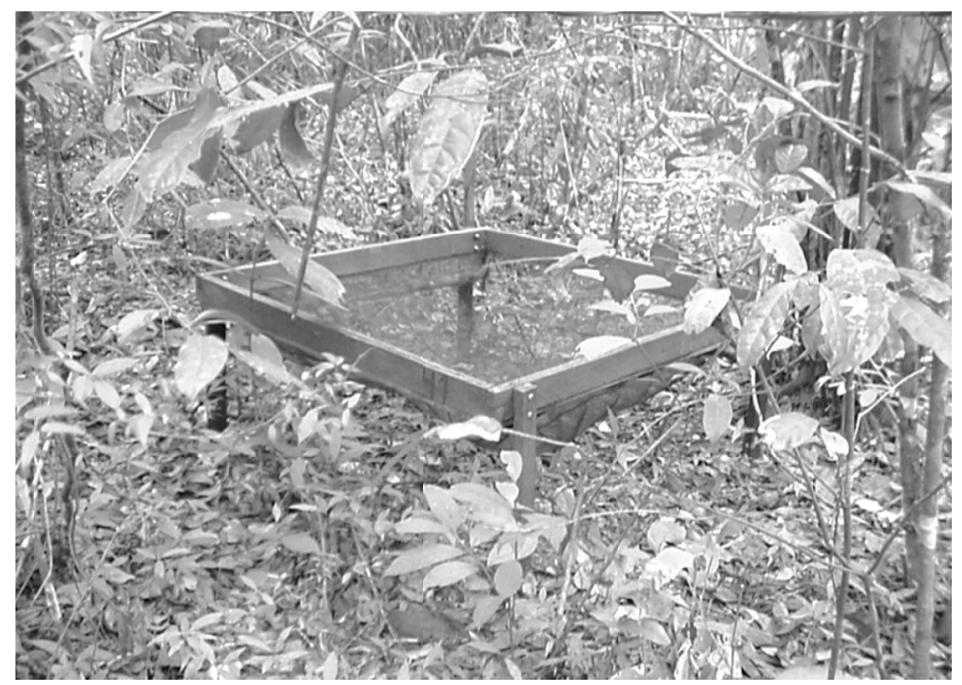

Figure 2. Litter collector in control treatment, installed $30 \mathrm{~cm}$ above the soil surface, in successional forest, Castanhal/PA

Samples of fractions of the biogeochemical matrix were classified as: i) non-woody (leaf, flower, seed, fruit and miscellaneous) and ii) woody $>3 \mathrm{~cm}$ (branches). The plant materials collected in each litter collector were dried in the laboratory at $60-70{ }^{\circ} \mathrm{C}$ for 48 hours and weighed. At four-week intervals, materials from the same collector were mixed and then separated into woody and non-woody fractions. Compounds from non-woody samples were grinded and stored in $60 \mathrm{ml}$ glass bottles.

For $\mathrm{Ca}$ and $\mathrm{Mg}$ analyses, $0.5 \mathrm{~g}$ subsamples were taken from an extract for chemical analysis of the elements, which was performed by atomic absorption spectrophotometry (Miyazawa et al., 1999; Rothery, 1986). The analyses were carried out at the Embrapa Eastern Amazon Soils Laboratory. The nutrient mass values were determined by multiplying the mean concentrations (ppm) of $\mathrm{Ca}$ and $\mathrm{Mg}$ by the dry mass values $\left(\mathrm{g} \mathrm{m}^{-2}\right)$ of the biogeochemical matrix of weekly collected litter.

\subsection{Statistical Analysis}

The analytical results were organized into sheets in the XLS format. MINITAB version 15 was used for all statistical analyses. We analyzed the treatment effects, time and the treatment $\mathrm{x}$ time interaction. When necessary, logarithmic and square root transformations were performed to meet the model requirements, such as normality tests and variance homogeneity, with significance criteria $(\mathrm{P}<0.05)$.

\section{Results}

In the successional forest ecosystem, during the study period, there were found 2,744 individuals belonging to 24 families and 29 species with a mean DBH of $2.61 \mathrm{~cm}$ and a mean height of $4.86 \mathrm{~m}$ in 1999, while in 2006 the mean DBH was $3.31 \mathrm{~cm}$ and the mean height was $6.82 \mathrm{~m}$.

The most representative families were Lacistemataceae and Myrtaceae, due to the large number of individuals of Lacistema pubescens Mart. (1,046) and Myrcia sylvatica Barb. Rodr. (595), respectively, totaling more than 60\% of the floristic composition of the area (Table 2). 
Table 2. List of dominant species identified in the experimental area of the Freshwater Fish Farming Station (EPAD), in the municipality of Castanhal, through a floristic survey

\begin{tabular}{llll}
\hline $\mathrm{N}$. & Species & Family & Common name \\
\hline 1 & Lacistema pubescens Mart. & Lacistemataceae & Passarinheira-H \\
2 & Myrcia sylvatica (G. Mey.) DC. & Myrtaceae & Murtinha \\
3 & Vismia guianensis (Aubl.) DC. & Clusiaceae & Lacre \\
4 & Cupania scrobiculata Rich. & Sapindaceae & Pau de espeto/andorinha \\
5 & Inga rubiginosa (Rich.) DC. & Mimosaceae & Ingá chato/Ingá peludo \\
6 & Myrcia bracteata (Rich.) DC. & Myrtaceae & Murta \\
7 & Banara guianensis Aubl. & Flacourtiaceae & Pau de picos/andorinha \\
8 & Miconia ciliata (Rich.) DC. & Melastomataceae & Chumbinho \\
9 & Inga flagelliformis (Vell.) Mart. & Mimosaceae & Ingá chato \\
10 & Inga thibaudiana DC. & Mimosaceae & Ingá cipó \\
11 & Chimarris turbinata DC. & Rubiaceae & Pau de remo \\
12 & Astrocaryum gynacanthum Mart. & Arecaceae & Mumbaca \\
13 & Couratari guianensis Aubl. & Lecythidaceae & Tauari \\
14 & Talisia Aubl. & Sapindaceae & Pitomba \\
15 & Stryphnodendron pulcherrirum (Willd.) Hochr. & Mimosaceae & Paricazinho \\
\hline
\end{tabular}

The monthly variation of total litter production during the periods from January to December 2000 and 2006 in the control and irrigated plots is shown in Figure 3b. The monthly litter production in 2000, in the control treatment, varied from $421.20 \mathrm{~kg} \mathrm{ha}^{-1}$ (March) to $997.90 \mathrm{~kg} \mathrm{ha}^{-1}$ (September), with a mean value of $644.40 \pm 225.90 \mathrm{~kg} \mathrm{ha}^{-1}$, representing a total of $7.73 \mathrm{Mg} \mathrm{ha}^{-1}$ year $^{-1}$ (Figure 3b). In this case, it is observed that the values are in the same period, but in this year the rainfall indices have been low since June (Figure 3a), indicating that the hydroperiodic phenomenon influences the litter dynamics in this ecosystem, evidencing the seasonality in the different periods studied (2000 and 2006). 

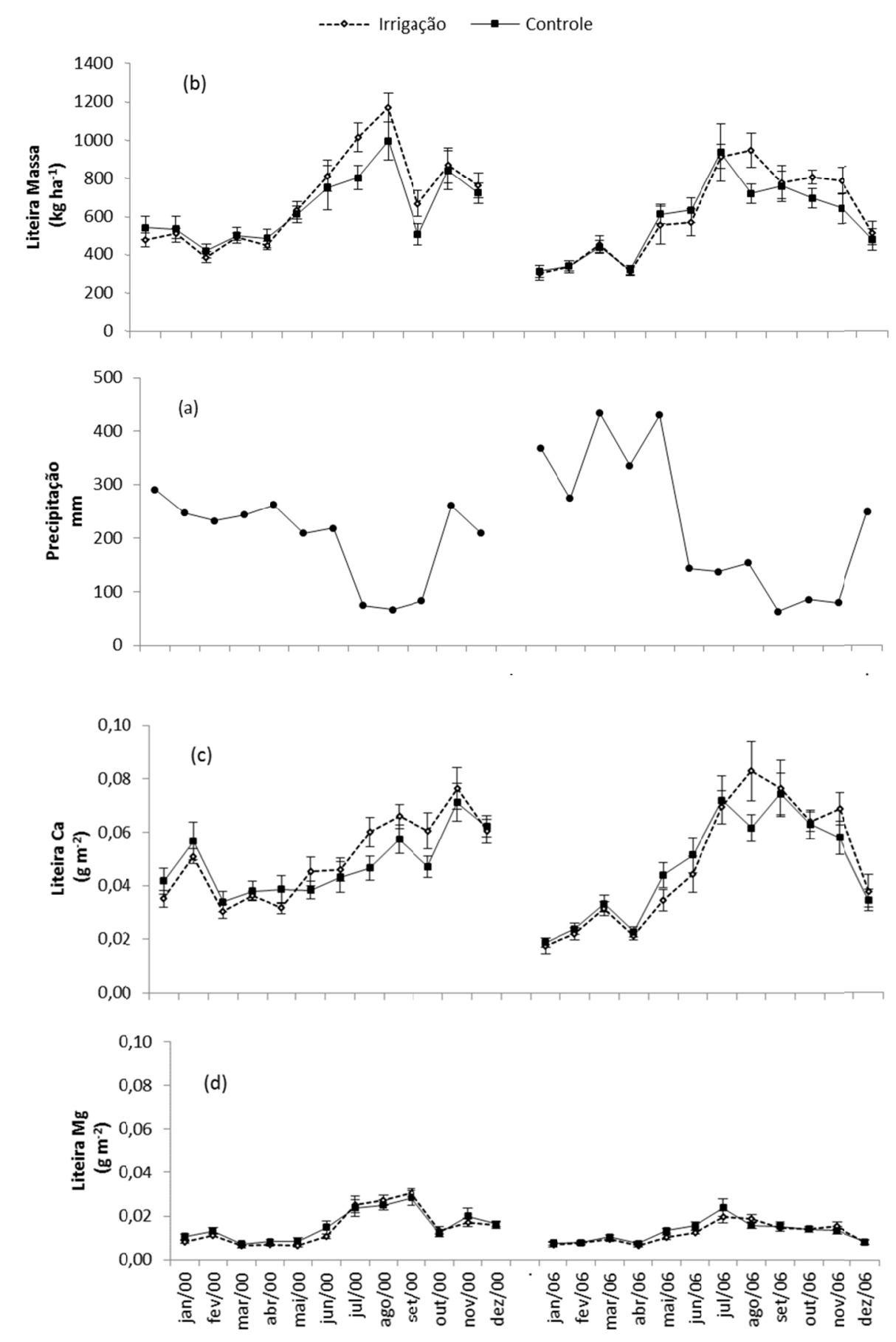

Figure 3. Dynamics of $\mathrm{Ca}$ and $\mathrm{Mg}$ masses in litter in control and irrigated treatments, in successional forest in Castanhal/PA. (a) Monthly rainfall, (b) non-woody litter mass, (c) Ca mass dynamics, (d) Mg mass dynamics

The monthly distribution of $\mathrm{Ca}$ and $\mathrm{Mg}$ masses are shown in Figures 3c and 3d, respectively, and were highly significant $(\mathrm{P}<0.01)$ only in time (Table 3$)$. 
Table 3. Variance analyses with associated significance levels for the effects of treatments (control and irrigated), sampling time and their interaction on non-woody mass and nutrients in a secondary rain forest in eastern Amazon, Brazil. The significance level is indicated (*: $\mathrm{P}<0.05, * *: \mathrm{P}<0.01$, ns: not significant)

\begin{tabular}{llll}
\hline \multirow{2}{*}{ Litter (non-woody) } & \multicolumn{3}{l}{ Irrigated experiment } \\
\cline { 2 - 4 } & Treatment & Time & Treatment $\times$ Time \\
\hline Monthly mass & $0.043^{*}$ & $0.000^{* *}$ & $0.613 \mathrm{~ns}$ \\
Ca monthly mass & $0.298 \mathrm{~ns}$ & $0.000^{* *}$ & $0.400 \mathrm{~ns}$ \\
Mg monthly mass & $0.171 \mathrm{~ns}$ & $0.000^{* *}$ & $0.933 \mathrm{~ns}$ \\
Ca monthly concentration & $0.012^{*}$ & $0.000^{* *}$ & $0.997 \mathrm{~ns}$ \\
Mg monthly concentration & $0.000^{* *}$ & $0.000^{* *}$ & $0.970 \mathrm{~ns}$ \\
Annual mass & $0.126 \mathrm{~ns}$ & $0.003^{* *}$ & $0.803 \mathrm{~ns}$ \\
Ca annual mass & $0.440 \mathrm{~ns}$ & $0.353 \mathrm{~ns}$ & $0.805 \mathrm{~ns}$ \\
Mg annual mass & $0.316 \mathrm{~ns}$ & $0.000^{* *}$ & $0.951 \mathrm{~ns}$ \\
Ca annual concentration & $0.060 \mathrm{~ns}$ & $0.348 \mathrm{~ns}$ & $0.581 \mathrm{~ns}$ \\
Mg annual concentration & $0.000^{* *}$ & $0.212 \mathrm{~ns}$ & $0.134 \mathrm{~ns}$ \\
\hline
\end{tabular}

In the control treatment, Ca production in 2000 was $5.74 \mathrm{~kg} \mathrm{ha}^{-1} \mathrm{year}^{-1}$, ranging from $0.034 \mathrm{~g} \mathrm{~m}^{-2}$ to $0.071 \mathrm{~g} \mathrm{~m}^{-2}$, with a mean value of $0.048 \pm 0.017 \mathrm{~g} \mathrm{~m}^{-2}$. In 2006 , the mean production was $0.047 \pm 0.017 \mathrm{~g} \mathrm{~m}^{-2}$, ranging from $0.019 \mathrm{~g} \mathrm{~m}^{-2}$ to $0.074 \mathrm{~g} \mathrm{~m}^{-2}$ with a total amount of $5.58 \mathrm{~kg} \mathrm{ha}^{-1} \mathrm{year}^{-1}$ (Table 4, Figure $3 \mathrm{c}$ ).

Table 4. Annual production of $\mathrm{Ca}$ and $\mathrm{Mg}$ via litter, under control and irrigated treatments, in 2000 and 2006 in $\mathrm{kg} \mathrm{ha}^{-1}$ year $^{-1}$

\begin{tabular}{llllll}
\hline \multirow{2}{*}{ Period } & \multicolumn{4}{c}{ Treatments } \\
\cline { 2 - 3 } \cline { 6 - 7 } \cline { 5 - 6 } & \multicolumn{3}{c}{ Control } & & \multicolumn{2}{c}{ Irrigated } \\
\cline { 2 - 3 } \cline { 6 - 7 } 2000 & $\mathrm{Ca}$ & $\mathrm{Mg}$ & & & $\mathrm{Ca}$ \\
\hline 2006 & 5.74 & 1.88 & & 5.99 & 1.79 \\
\hline
\end{tabular}

In the control treatment, the annual production of $\mathrm{Mg}$ in the litter flow was $1.88 \mathrm{~kg} \mathrm{ha}^{-1} \mathrm{year}^{-1}$, with a monthly mean of $0.016 \pm 0.007 \mathrm{~g} \mathrm{~m}^{-2}$ in 2000 , and $1.53 \mathrm{~kg} \mathrm{ha}^{-1}$ year $^{-1}$ in 2006 , with a monthly mean of $0.013 \pm 0.005 \mathrm{~g} \mathrm{~m}^{-2}$. On the other hand, in the irrigated treatment the $\mathrm{Mg}$ production was $1.79 \mathrm{~kg} \mathrm{ha}^{-1}$ in 2000 , with a mean value of $0.015 \pm 0.005$ and in 2006 the total production was $1.44 \mathrm{~kg} \mathrm{ha}^{-1}$ year ${ }^{-1}$, with a mean value of $0.012 \pm 0.005 \mathrm{~g} \mathrm{~m}^{-2}$ (Figure 4b). 

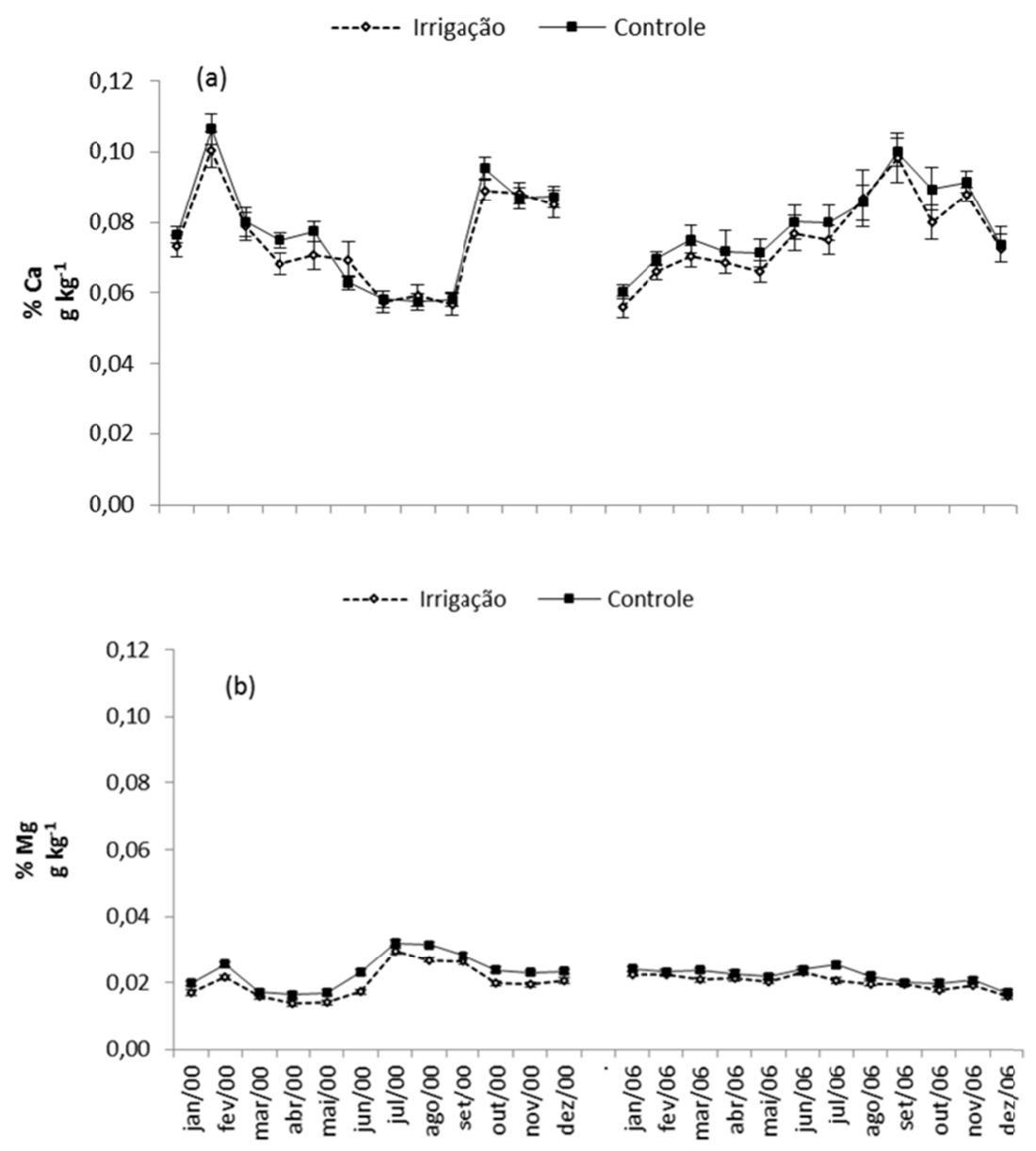

Figure 4. Dynamics of $\mathrm{Ca}$ and $\mathrm{Mg}$ concentration in control and irrigated treatments in successional forest in Castanhal/PA. (a) Ca concentration and (b) Mg concentration

\section{Discussion}

As for the species, the number found in this experiment was considered low, but it followed the pattern of the secondary forests of the Bragantina Zone, which have few species. The vegetation is the main responsible for the horizontal variability of the litter, that is, the more diverse the plant community, the more heterogeneous the litter (Correia \& Andrade, 1999), as well as the amount of nutrients that will be available to be reused by the forest community.

The most abundant species in the area, besides the ones mentioned above, were Vismia guianensis (Aublet.) Pers. (134), Cupania scrobiculata Rich. (131) and Inga sp. (Lima, 2003), which were also very abundant in the upper stratum of this forest.

These species are considered pioneers in the secondary forests of Bragantina Zone (Oliveira, 1995; Vieira, 1996; Santana, 2000). The most peculiar habit of the vegetation was tree, which indicates that the forest is at a more advanced stage of succession (Smith et al., 1997). In addition, the species differ from each other in their absorption capacities, that is, it depends on some aspects such as porosity of the deposited material, decomposition rate, precipitation variation and environmental temperatures (Santos Junior, 2020).

Factors affecting nutrient form and cycling are closely linked to climatic and phenological conditions, as well as to environmental aspects and pollutants, varying from species to species (Schumacher, 1992; Poggiani \& Schumacher, 2000).

On the forest litter, the minimum and maximum values are found in different periods, since March is a typical month of the rainy season and September one of the dry season, so that there is a seasonal control of hydroperiodicity. For Santos Junior (2020), among the factors that contribute to the variation in litter storage, climate is one of the biggest drivers, especially precipitation. 
Leaf fall is caused by senescence, resulting from a series of metabolic processes linked to the physiology of each species, as well as by environmental stimuli such as photoperiod, temperature and water stress (Kramer \& Kozlowski, 1960). However, in 2006, the annual litter quantity in the control treatment reduced to $6.91 \mathrm{Mg} \mathrm{ha}^{-1}$ year $^{-1}$ when compared to the irrigated treatment, ranging from $316.10 \mathrm{~kg} \mathrm{ha}^{-1}$ (January) to $937.90 \mathrm{~kg} \mathrm{ha}^{-1}$ (July), with monthly mean of $575.96 \pm 202.60 \mathrm{~kg} \mathrm{ha}^{-1}$. In addition, the litter flow varies according to the ecosystem considered and its successional stage (Delitti, 1989).

The annual production in successional ecosystems in plateau areas in the Amazon is in the range of $7-10 \mathrm{Mg}^{-1}$ year $^{-1}$ (Klinge \& Rodrigues, 1968; Stark, 1971; Herrera et al., 1978; Vitousek, 1984; Vasconcelos et al., 2008), but it can vary considerably from one year to the next, depending on the phenology of tree species and, mainly, on rainfall patterns, because there is a strong seasonal control of thin litter production: larger productions are measured in the driest periods of the year (Luizão, 1989). Therefore, the litter layer on the soil also presents a strong seasonal pattern, decreasing its thickness at the end of the rainy season and increasing it in the dry period (Luizão \& Schubart, 1987).

The irrigated treatment presented an annual deposition of $8.26 \mathrm{Mg} \mathrm{ha}^{-1}$ year $^{-1}$ in 2000 , with a mean monthly value of $688.76 \pm 183.00 \mathrm{~kg} \mathrm{ha}^{-1}$, ranging from $388.20 \mathrm{~kg} \mathrm{ha}^{-1}$ (March) to $1171.60 \mathrm{~kg} \mathrm{ha}^{-1}$ (September). In 2006, the annual deposition decreased to $7.29 \mathrm{Mg} \mathrm{ha}^{-1} \mathrm{year}^{-1}$, with a monthly mean value of $607.91 \pm 205.80 \mathrm{~kg} \mathrm{ha}^{-1}$, which varied from $305.70 \mathrm{~kg} \mathrm{ha}^{-1}$ (January) to $949.20 \mathrm{~kg} \mathrm{ha}^{-1}$ (August).

The irrigated treatment had a greater litter production than the control plot, that is, the artificial hydroperiodic pulses probably contributed to a higher phytomass deposition in this ecosystem, which may have caused an ecophysiological disturbance on the plants, in relation to water availability outside the rainy season. However, there was no significant interaction on treatment $\times$ time (Table 3, Figure 3b). For the annual mass, only for time it was highly significant $(\mathrm{P}<0.01)$.

In forestry cultivation, irrigation has been used mainly in the first year of stomatal formation, presenting stomatal closure under conditions of high evaporative demand, which may have variable or gradual effects depending on the stage of development (Amaral, 2019). The variation of water in the soil directly influences transpiration and conductance.

For Delitti (1984), the increase in litter quantity with low rainfall is common in tropical regions and reflects a strategy of minimizing the effects of water scarcity. In tropical regions such as the Amazon, the influence of rainfall is of fundamental importance for the accumulation, decomposition rate and release of nutrients from the litter (Luizão, 1982). The monthly distribution of $\mathrm{Ca}$ and $\mathrm{Mg}$ masses are shown in Figures 3c and 3d, respectively, and were highly significant $(\mathrm{P}<0.01)$ only in time (Table 3$)$.

$\mathrm{Ca}$ dynamics were significant both in the dry season and in the rainy season. However, considering that it is proportionally associated to the pulses of monthly litter production, which are higher in the dry period, the dynamics of $\mathrm{Ca}$ become more pronounced in the latter. The monthly water pulses in the irrigated treatment, the Ca mass, in 2000 , ranged from $0.031 \mathrm{~g} \mathrm{~m}^{-2}$ to $0.076 \mathrm{~g} \mathrm{~m}^{-2}$, with a mean value of $0.050 \pm 0.015 \mathrm{~g} \mathrm{~m}^{-2}$, totaling 5.99 $\mathrm{kg} \mathrm{ha}^{-1}$ year $^{-1}$. In 2006, the average monthly production was $0.048 \pm 0.018 \mathrm{~g} \mathrm{~m}^{-2}$, corresponding to a total of 5.71 $\mathrm{kg} \mathrm{ha}^{-1}$ year ${ }^{-1}$.

Comparing the monthly distribution in the years studied (2000 and 2006) in the dry period (August to December), when rainfall is lower than $100 \mathrm{~mm}$, it is observed that the deposited amount of Ca in both treatments was higher than the one of Mg. Calcium dynamics is high in most of the tropical forests studied (Vitousek, 1984), because it is a fixed element in plant tissues (leaf, bark, wood and branches), however, there was not a marked difference between the treatments.

The concentration and nutrient content of the litter varies according to soil type, vegetation, population density, species ability to absorb, utilize and redistribute nutrients, natural habitat and tree age. The monthly concentration of $\mathrm{Ca}$ (Figure 3 ) and $\mathrm{Mg}$ (Figure 3 ) varied significantly $(\mathrm{P}<0.05)$ in treatment and in time, but only Mg concentration was highly significant $(\mathrm{P}<0.01)$ and only by treatment (Table 3, Figures $4 \mathrm{a}$ and $4 \mathrm{~b}$ ).

According to Yavitt et al. (2004) irrigation did not have a significant effect on the concentration or fall of leaves or amount of nutrient return annually by leaf fall. The temporal patterns in nutrient concentrations tended to accompany those in the leaf fall. The biogeochemical cycle encompasses the processes of nutrient transferring within the soil-plant system. The nutrients cycling depends on several factors, including their mobility within the plant.

According to Mengel and Kirkby (1982), the biochemical cycle, which represents the movement of translocation of nutrients from old to new tissues of the plant, is of fundamental importance for high mobility nutrients such as 
$\mathrm{Mg}$. Nonetheless, it is of less significance to those of limited redistribution such as $\mathrm{Ca}$. In addition, much of the nutrients is allocated in the trees. Among the components of the aerial part of the tree, the highest nutrient content is found in the leaves, then in the branches and the rest in the wood and trunk (Vieira, 1998). Therefore, $\mathrm{Ca}$ values are higher in relation to $\mathrm{Mg}$ due to the higher deposition of senescent tissues, such as leaves, and their low mobility.

\section{Conclusion}

The seasonality of total litter production was significative, being higher in dry season, regardless of irrigation performed in dry period, in the irrigated treatment. The annual litter production did not show significant differences between control and irrigated treatments. However, a longer observation period would be necessary to confirm the information more conclusively or to obtain more significant results for irrigated treatment.

The litter quality in the successional forest ecosystem with predominant species Lacistema pubescens Mart. $(1,046)$ and Myrcia sylvatica Barb. Rodr. showed a significant mobilization of $\mathrm{Ca}$, in relation to $\mathrm{Mg}$, in quantity (production) and concentration, regardless of time and treatment, i.e., those species mobilize nutrients fixed in the soil and provide for plants that are installed in secondary forest.

\section{References}

Amaral, A. M. (2019). Fluxo de seiva e transpiração de plantas jovens de mogno brasileiro (Swietenia Macrophylla King) sob regime variável de água no solo (77f., Tese de Doutorado em Ciências Agrárias, Instituto Federal Goiano, Rio Verde).

Barroco Neta, E. F., \& Nishiwaki, E. (2018). Variações sazonais na ciclagem de nutrientes em uma floresta da Amazônia Central. Brazilian Applied Science Review, 2, 1747-1759. Retrieved from https://www.brazilian journals.com/index.php/BASR/article/view/563/486

Brasil. (1974). Geologia, geomorfologia, solos, vegetação e uso potencial da terra (Projeto RADAM, Folha AS 23, p. 184). Departamento Nacional de Produção Mineral, Rio de Janeiro.

Clevelário Júnior, J. (1988). Quantificação da massa do reservatório de nutrientes na serapilheira da bacia do Alto Rio da Cachoeira, Parque Nacional da Tijuca, e avaliação da sua participação na ciclagem de nutrients (152f., Dissertação (Mestrado em Geoquímica), Universidade Federal Fluminense, Niterói).

Correia, M. E. F., \& Andrade, A. G. (1999). Formação de serapilheira e ciclagem de nutrientes. In G. A. Santos \& F. A. O. Camargo (Eds.), Fundamentos da matéria orgânica do solo: Ecossistemas tropicais e subtropicais (p. 490). Porto Alegre: Gênesis.

Delitti, W. B. C. (1984). Aspectos comparativos da ciclagem de nutrientes minerais na mata ciliar, no campo cerrado e na floresta implantada de Pinus elliottii var. elliottii (248f., Tese (Doutorado em Biociências), Universidade de São Paulo, São Paulo).

Delitti, W. B. C. (1989). Ciclagem de nutrientes minerais em matas ciliares (pp. 88-98). Simpósio Sobre Mata Ciliar, 1989, Anais... Fundação Cargil, Secretaria do Meio Ambiente, Instituto de Botânica, São Paulo.

Falesi, I. C., Baena, A. R. C., \& Dutra, S. (1980). Consequências da exploração agropecuária sobre as condições físicas e químicas dos solos das microrregiões do nordeste Paraense. Boletim de Pesquisa (Vol. 14, p. 49), Embrapa-CPATU, Belém.

Figueroa, S. N., \& Nobre, C. (1990). Precipitations distribution over Central and Western Tropical South America. Boletim de Monitoramento e Análise Climática, 5, 36-48.

Golley, F. B., Mcginnis, J. T., Clements, R. G., Child, G. I., \& Duever, M. J. (1978). Ciclagem de minerais em um ecossistema de floresta tropical úmida. Tradução: Eurípedes Malavolta. São Paulo: EDUSP.

Herrera, R., Jordan, C. F., Klinge, H., \& Medina, E. (1978). Amazon ecosystems: Their structure and functioning with particular emphasis on nutrients. Interciencia, 3, 223-232. Retrieved from https://www.academia.edu/ download/40987317/1978_Amazon_Ecosystems.pdf

Jipp, P. H., Nepstad, D. C., Cassel, D. K., \& De Carvalho, C. R. (1998). Deep soil moisture storage and transpiration in forest and pastures of seasonally-dry Amazonia. Climatic Change, 39, 395-412. https://doi.org/10.1023/A:1005308930871

Klinge, H., \& Rodrigues, W. (1968). Litter production in an area of Amazonian terra firme forest: Part II-Mineral Nutrient Content of the Litter. Amazoniana, 1, 303-310. 
Kramer, R. J., \& Koslowski, T. T. (1960). Fisiologia das árvores (p. 745). Lisboa: Fundação Kalouste Gouldbenkian.

Lean, J., Bunton, C. B., Nobre, C. A., \& Rowntree, P. R. (1996). The simulated impact of Amazonian deforestation on climate using measured ABRACOS vegetation characteristics. In R. L. Victoria (Ed.), Amazonian deforestation and climate (pp. 549-576). John Wiley e Sons, New York.

Lima, C. A. T. (2003). Regeneração natural de uma floresta secundaria sob manipulação de água e nutriente no município de castanhal, Pará (59f., Dissertação (Mestrado em Ciências Florestais), Universidade Federal Rural da Amazônia, Belém).

Luizão, F. (1982). Produção e decomposição de liteira em floresta de terra firme da Amazônia Central: aspectos químicos e biológicos da lixiviação e remoção de nutrientes da liteira (109f., Dissertação (Mestrado em Ecologia), Instituto Nacional de Pesquisas da Amazônia, Fundação Universidade do Amazonas, Manaus).

Luizão, F. J. (1989). Litter production and mineral element input to the forest floor in a Central Amazonian forest. GeoJournal, 19, 407-417. https://doi.org/10.1007/BF00176910

Luizão, F. J., \& Schubart, H. O. R. (1987). Litter production and decomposition in a terra-firme forest of Central Amazonia. Experientia, 43, 259-265. https://doi.org/10.1007/BF01945549

Martorano, L. G., \& Pereira, L. (1993). Estudos climáticos do Estado do Pará, classificação climática (Koppen) e deficiência hídrica (THORNTHWAITE) (p. 50). SUDAM/Embrapa.

Mateus, F. A., Miranda, C. C., Valcarcel, R., \& Figueiredo, P. H. A. (2013). Estoque e capacidade de retenção hídrica da serapilheira acumulada na restauração florestal de áreas perturbadas na Mata Atlântica. Floresta e Ambiente, 20, 336-343. https://doi.org/10.4322/floram.2013.024

Mengel, K., \& Kirkby, E. A. (1982). Principles of plant nutrition (p. 655). Bern: International Potash Institute.

Miyazawa, M., Pavan, M. A., Muraoka, T., Carmo, C. A. F. S., \& Mello, W. J. (1999). Análises químicas de tecido vegetal. In F. C. Silva (Ed.), Manual de análises químicas de solo, plantas e fertilizantes (pp. 173-223). Brasília: Embrapa.

Nascimento, A. F. J., Silva, T. D. O., Araújo, R. N., Sampaio, E. V. D. S. B., Pedrotti, A., Gonzaga, M. I. S., \& Piscoya, V. C. (2018). Produção e aporte de carbono, nitrogênio e fósforo na serapilheira foliar do parque nacional serra de Itabaiana. Ciência Florestal, 28(1), 35-46. https://doi.org/10.5902/1980509831573

Nepstad, D. C., Uhl, C., Pereira, C., \& Silva, J. M. C. (1998). Barreiras ao estabelecimento de arvores em pastos abandonados na Amazônia: Banco de sementes, predação de sementes, herbivoria e seca. In C. Gascon \& P. Moutinho (Eds.), Floresta amazônica: dinâmica, regeneração e manejo (pp. 191-218).

Odum, E. P. (1988). Ciclos biogeoquímicos. In E. P. Odum (Ed.), Ecologia (pp. 111-136). Guanabara, Rio de Janeiro, RJ.

Oliveira, L. C. (1995). Dinâmica de crescimento e regeneração natural de uma floresta secundária do estado do Pará (126f., Dissertação (Mestrado em Ciência Biológica), Universidade Federal do Pará, Belém).

Pimentel, C., Neto Jacob, J., Goi, S. R., \& Pessanha, G. G. (1990). Estresse hídrico em cultivares de Phaseolus vulgaris L. em simbiose com o Rhizobium leguminosarus biovar phaseoli. Turrialba, 40, 520-526. Retrieved from http://hdl.handle.net/11554/10565

Poggiani, F., \& Schumacher, M. V. (2000). Ciclagem de nutrientes em florestas nativas. In J. L. M. Gonçalves \& V. Benedetti (Eds.), Nutrição e fertilização florestal (p. 427). Piracicaba: IPEF.

Proctor, J. (1983). Tropical Forest Litterfall I: Problems of data comparison. In A. Sutton \& C. Chadwick (Eds.), Tropical Rain Forest: The Leeds Symposium (pp. 83-113). Leeds: Leeds Philos. Nat. Hist Soc.

Rangel-Vasconcelos, L. G. T. (2002). Biomassa microbiana de solo sob vegetação secundária na Amazônia oriental (p. 76, Master thesis, Faculdade de Ciências Agrárias do Pará, Belém).

Rocha, E. J. P. (2001). Balanço de Umidade e Influências de Condições de Contorno Superficiais Sobre a Precipitação da Amazônia (210f., Tese (Doutorado em Meteorologia), Instituto Nacional de Pesquisas Espaciais, INPE, São Paulo).

Rothery, E. (1986). Operation manual SpetrAA-300 (p. 180). Melbourne: Varian Australia Pty Ltd.

Santana, J. A. S. (2000). Composição florística de uma vegetação secundária no nordeste paraense. Serviço de documentação e informação (FCAP, Informe Técnico, 26, p. 27). Belém: FCAP. 
Santos Junior, H. B. (2020). Fitossociologia e propriedades fisicas da liteira em ecossistema sucessional de floresta alterada na Amazônia Oriental (58f., Dissertação de Mestrado em Ciências Florestais, Universidade Federal Rural da Amazônia, Belém). https://doi.org/10.14808/sci.plena.2021.060202

Santos, P. M., Alves Júnior, J., Sena, C. C., Domingos, M. V. H., Evangelista, A. W. P., Derblai, C., ... Sousa, J. M. F. (2020). Necessidade de se irrigar a fase inicial de floresta de Mogno-Africado no cerrado. Brazilian Journal of Development, 6(6), 41399-41409. https://doi.org/10.34117/bjdv6n6-615

Santos, S. H. M. (1996). Comportamento fisiológico de plantas jovens de espécies florestais sob diferentes regimes de água no solo (117f., Dissertação (Mestrado em Agronomia/Fisiologia Vegetal), Universidade Federal de Lavras, Lavras). Retrieved from http://repositorio.ufla.br/handle/1/36341

Schumacher, M. V. (1992). Aspectos da ciclagem de nutrientes e do microclima em talhões de Eucalyptus camaldulensis Dehnh, Eucalyptus grandis Hill ex Maiden e Eucalyptus toreliana F. Muell (87f., Dissertação (Mestrado em Ciências Florestais), Escola Superior de Agricultura de Luiz de Queiroz, Piracicaba). https://doi.org/10.11606/D.11.2019.tde-20191218-150559

Silva, C. F., Carmo, E. R., Martins, M. A., Freitas, M. S. M., Pereira, M. G., \& Silva, E. M. R. (2015). Deposition and nutritional quality of the litter of pure stands of Eucalyptus camaldulensis and Acacia mangium. Bioscience Journal, 31, 1081-1091. https://doi.org/10.14393/BJ-v31n4a2015-26297

Sinclair, T. R., \& Ludlow, M. M. (1985). Who taught plants thermodynamics? The unfulfilled potential of plant water potential. Australian Journal of Plant Physiology, 12(3), 213-217. https://doi.org/10.1071/PP9850213

Smith, M. D., Larson, B. C., Kelty, M. J., \& Ashton, P. M. S. (1997). Stand dynamic. In M. D. Smith (Ed.), The Practice of Silviculture. Applied Forest Ecology (pp. 20-41). New York: John Wiley e Sons, Inc.

Sobrinho, O. P. L., Silva, G. S. da, Santos, L. N. S. dos, Castro Júnior, W. L., Pereira, A. I. S.; Teixeira, M. B., ... Soares, J. A. B. (2020). Dendrometry techniques in irrigation management: an integrative review. Research, Society and Development, 9(8), e343984837. https://doi.org/10.33448/rsd-v9i8.4837

Sommer, R., Sá, T. D. D. A., Vielhauer, K., Araújo, A. C. D., Folster, H., \& Vlek, P. L. G. (2002). Transpiration and canopy conductance of secondary vegetation in the eastern Amazon. Agricultural and Forest Meteorology, 112, 103-121. https://doi.org/10.1016/S0168-1923(02)00044-8

Stark, N. (1971). Nutrient cycling II: nutrient distribution in amazonian vegetation. Tropical Ecology, 12, 177-201.

Summers, P. M. (1998). Estoque, decomposição e nutrientes da liteira grossa em floresta de terra firme na Amazônia central (103f., Dissertação (Mestrado em Ciências de Florestas Tropicais), Instituto Nacional de Pesquisas da Amazônia, UFAM, Manaus). Retrieved from https://repositorio.inpa.gov.br/handle/1/5408

Tenório, A. R. M., Graça, J. J. C., Góes, J. E. M., Mendes, J. G. R., Gama, J. R. N. F., Silva, P. R. O., ... Pereira, W. L. M. (1999). Mapeamento dos solos da Estação de Piscicultura de Castanhal. Serviço de documentação e informação (FCAP, Informe Técnico, 25, pp. 1-27). Belém: FCAP.

Vasconcelos, S. S., Zarin, D. J., Araújo, M. M., Rangel-Vasconcelos, L. G. T., Carvalho, C. J. R., Staudhmmer, C. L., \& Oliveira, F. A. (2008). Effects of seasonality, litter removal and dry-season irrigation on litterfall quantity and quality in eastern Amazonian Forest regrowth, Brasil. Journal of Tropical Ecology, 24, 27-38. https://doi.org/10.1017/S0266467407004580

Vieira, I. C. G. (1996). Forest succession after shifting cultivation in eastern Amazonian (205f., Thesis of Doctorate, University of Sterling, Scotland).

Vieira, S. A. (1998). Efeito das plantações florestais (Eucalyptus sp.) sobre a dinâmica de nutrientes em região de cerrado do Estado de São Paulo (73f., Dissertação (Mestrado em Ciências Florestais), Escola Superior de Agricultura de Luiz de Queiroz. Universidade de São Paulo, Piracicaba).

Vieira, S., Camargo, P. B., Selhorst, D. R., Silva, R., Hutyra, L., Chambers, J. Q., ... Martinelli, L. A. (2004). Forest structure and carbon dynamics in Amazonian tropical rain forests. Oecologia, 140, 468-479. https://doi.org/10.1007/s00442-004-1598-z

Vitousek, P. M. (1984). Litterfall, nutrient cycling and nutrients in tropical forests. Ecology, 65, 285-298. https://doi.org/10.2307/1939481

Vitousek, P. M., \& Sanford Jr., R. L. (1986). Nutrient cycling in moist tropical forest. Annual Review of Ecology and Systematics, 17, 137-167. https://doi.org/10.1146/annurev.es.17.110186.001033 
Yavitt, J. B., Wright, S. J., \& Wieder, R. K. (2004). Seasonal drought and dry-season irrigation influence leaf-litter nutrients and soil enzymes in a moist, lowland forest in Panama. Austral Ecology, 29, 177-188. https://doi.org/10.1111/j.1442-9993.2004.01334.x

Zhang, H., Yuan, W., Dong, W., \& Liu, S. (2014). Seasonal patterns of litterfall in forest ecosystem worldwide. Ecological Complexity, 20, 240-247. https://doi.org/10.1016/j.ecocom.2014.01.003

\section{Copyrights}

Copyright for this article is retained by the author(s), with first publication rights granted to the journal.

This is an open-access article distributed under the terms and conditions of the Creative Commons Attribution license (http://creativecommons.org/licenses/by/4.0/). 